\title{
Mass spectrometric identification of dystrophin isoform Dp427 by on-membrane digestion of sarcolemma from skeletal muscle
}

\author{
Caroline Lewis, Kay Ohlendieck* \\ Department of Biology, National University of Ireland, Maynooth, Co. Kildare, Ireland
}

\section{A R T I C L E I N F O}

\section{Article history:}

Received 25 February 2010

Received in revised form 6 May 2010

Accepted 20 May 2010

Available online 25 May 2010

\section{Keywords:}

Dystrophin

Sarcoglycan

Syntrophin

Sarcolemma

On-membrane digestion

Muscle proteomics

\begin{abstract}
A B S T R A C T
Although the membrane cytoskeletal protein dystrophin of $427 \mathrm{kDa}$ and its tightly associated glycoprotein complex are drastically affected in muscular dystrophy, recent large-scale proteomic investigations did not identify full-length dystrophin in muscle preparations and were unable to determine its molecular fate in dystrophinopathy. Because conventional two-dimensional gel electrophoresis underrepresents many low-abundance and membrane-associated protein species and in-gel trypsination is often hampered by an inefficient digestion of certain target proteins, here we have applied direct on-membrane digestion of one-dimensional blots of the sarcolemma-enriched fraction and the isolated dystrophinglycoprotein complex. This method succeeded in the mass spectrometric identification of dystrophin isoform Dp427 and associated glycoproteins as well as sarcolemmal dysferlin. In addition, protein bands representing established signature molecules of cross-contaminating membrane systems, such as the voltage-sensing dihydropyridine receptor of transverse tubules, the ryanodine receptor $\mathrm{Ca}^{2+}$-release channel of triad junctions, and the $\mathrm{Ca}^{2+}$-ATPase of the sarcoplasmic reticulum, were identified by mass spectrometry. Thus, proteomic approaches using on-membrane digestion might be suitable for future studies of low-abundance proteins, integral proteins, peripheral membrane proteins, and high-molecular-mass proteins. On-membrane digestion has the potential to develop into the method of choice for studying these classes of proteins, whose presence is otherwise missed by conventional gel electrophoresis-based proteomics.
\end{abstract}

(c) 2010 Elsevier Inc. All rights reserved.
The sarcolemma provides a crucial structural attachment site for the basement membrane at the outside of the muscle cell and for the membrane cytoskeleton on the inside of contractile fibers, strengthening the muscle periphery during contraction-relaxation cycles. The membrane cytoskeletal protein dystrophin and its tightly associated glycoprotein complex play a key role in the stabilization of the fiber surface by providing a linkage between the extracellular matrix component laminin and the cortical actin cytoskeleton [1-3]. Full-length dystrophin has a molecular mass of apparent $427 \mathrm{kDa}$ and exhibits a complex domain structure. The membrane cytoskeletal element consists of an N-terminal actin-binding domain, a central spectrin-like rod domain with proline-rich hinge regions, a cysteine-rich domain, and a C-terminal region containing membrane-binding sites [4]. Although biochemical and cell biological studies have clearly shown that the primary genetic deficiency of dystrophin results in the drastic reduction of the dystrophin-associated glycoprotein complex in X-linked muscular dystrophy [5], recent large-scale proteomic studies have surprisingly not identified dystrophin isoform Dp427 in gel electrophoretically separated muscle preparations [6-9]. Mass

\footnotetext{
* Corresponding author. Fax: +35317083845.

E-mail address: kay.ohlendieck@nuim.ie (K. Ohlendieck).
}

spectrometric approaches also failed to identify integral dystrophin-associated glycoproteins in the accessible total muscle proteome [9]. Thus, gel electrophoresis-based proteomics has revealed changes in many novel signature molecules of muscular dystrophy [10], such as the enzyme adenylate kinase [6], the luminal $\mathrm{Ca}^{2+}$ binding protein calsequestrin [7], the cytosolic $\mathrm{Ca}^{2+}$-binding protein regucalcin [8], and the small stress protein cvHsp [9], but appears not to be suitable for detecting alterations in elements of the dystrophin-glycoprotein complex.

This is probably related to the fact that conventional two-dimensional gel electrophoresis underrepresents many low-abundance and membrane-associated protein species [11-13]. In addition, an inefficient digestion of certain target proteins often hampers in-gel trypsination procedures. To address these technical shortcomings in the proteomic identification and biochemical analysis of dystrophin, here we have investigated whether direct on-membrane digestion of one-dimensional blots containing the sarcolemma-enriched fraction or the isolated dystrophin-glycoprotein complex from skeletal muscle can overcome these methodological problems. In general, proteins adsorbed onto nitrocellulose sheets are more accessible to proteases, increasing the digestion efficiency [14]. On-membrane trypsination methods have been applied in various biochemical studies [14-17]. The advantages of on-membrane 


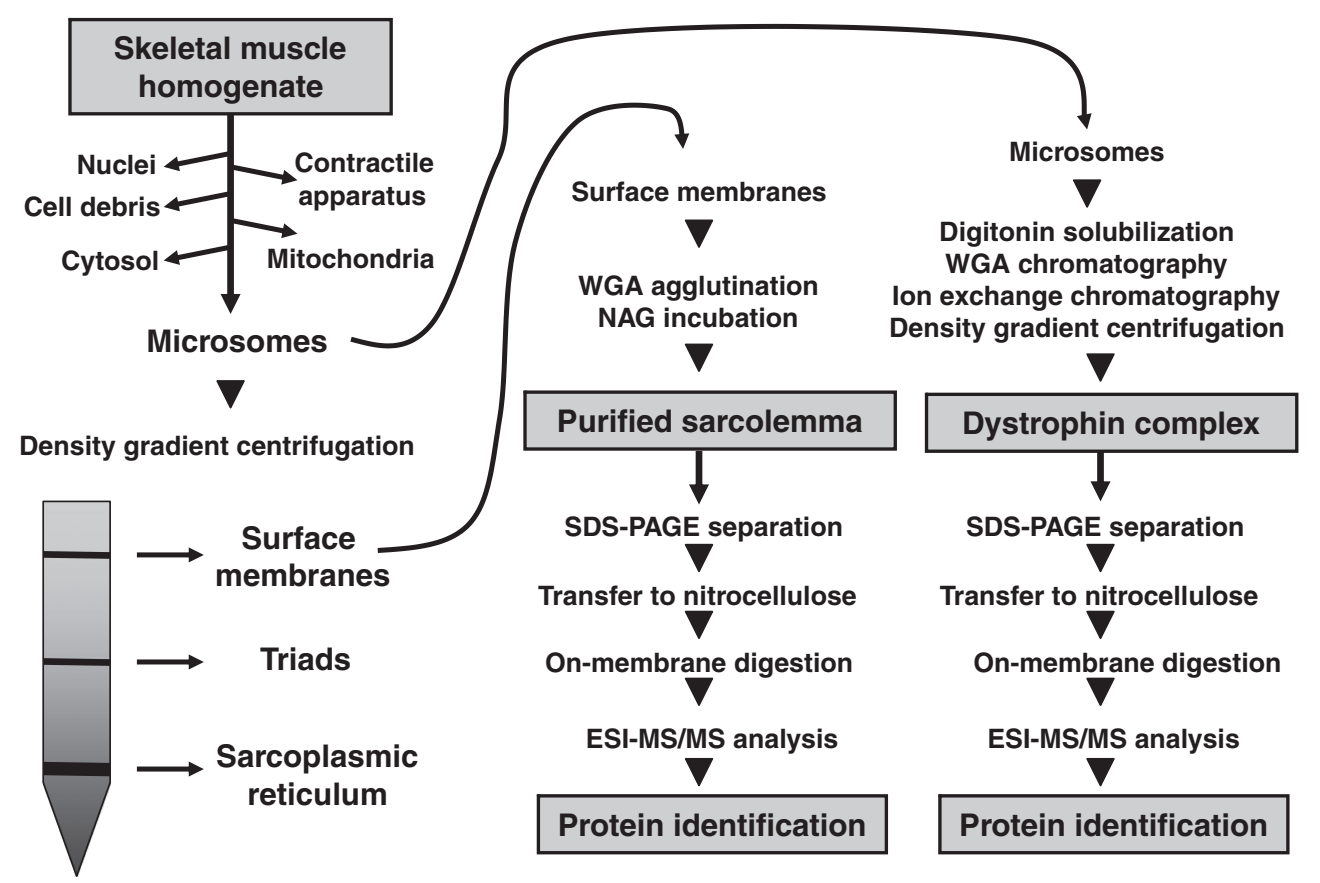

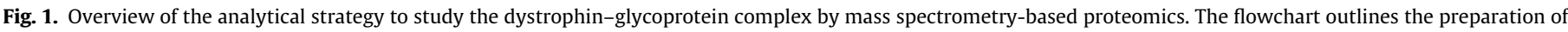

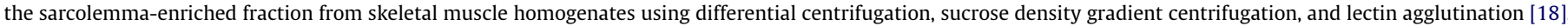

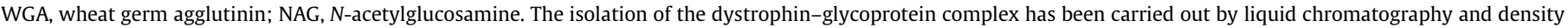

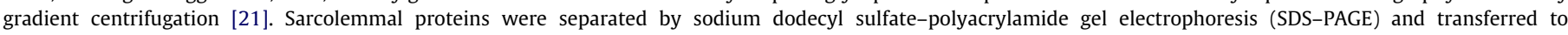

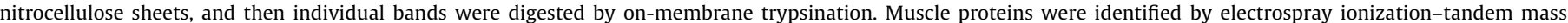
spectrometry (ESI-MS/MS).

methodology are better protein sequence coverage and a shorter digestion time as compared with in-gel techniques. This reduces complications due to trypsin autolysis and makes this method especially suitable for the mass spectrometric identification of lowabundance and large membrane-associated proteins [16].

This article describes the successful application of on-membrane digestion for the biochemical identification of full-length dystrophin, $\alpha$-sarcoglycan, $\gamma$-sarcoglycan, and $\alpha$-syntrophin by mass spectrometry. Hence, this technique might also be useful for the routine analysis of the dystrophin-glycoprotein complex in normal and pathological muscle samples. Importantly, other membrane-associated protein components, such as the dihydropyridine receptor of the transverse tubules and the ryanodine receptor $\mathrm{Ca}^{2+}$-release channel of the junctional sarcoplasmic reticulum, were identified by mass spectrometry. Thus, on-membrane digestion appears to be generally suitable for studying high-molecular-mass muscle proteins that would otherwise not be properly recognized by conventional two-dimensional gel electrophoretic approaches.

\section{Materials and methods}

\section{Materials}

For gel electrophoretic protein separation, analytical grade chemicals and materials were purchased from Amersham Biosciences/GE Healthcare (Little Chalfont, Buckinghamshire, UK), BioRad Laboratories (Hemel-Hempstead, Hertfordshire, UK), and National Diagnostics (Atlanta, GA, USA). The reversible membrane stain MemCode and Coomassie Brilliant Blue G-250 dye were purchased from Thermo Fisher Scientific (Waltham, MA, USA). Sequencing grade modified trypsin was obtained from Promega (Madison, WI, USA). Liquid chromatography-mass spectrometry
(LC-MS) ${ }^{1}$ CHROMASOLV water and formic acid were obtained from Fluka (Milwaukee, WI, USA). Protease inhibitors were purchased from Roche Diagnostics (Mannheim, Germany). All other chemicals used were of analytical grade and purchased from Sigma Chemical (Dorset, UK).

\section{Isolation of sarcolemma-enriched fraction}

Purified sarcolemma vesicles were prepared from New Zealand white rabbit hind leg muscle homogenates by an established lectin agglutination technique [18-20]. Membrane fractions enriched in sarcoplasmic reticulum, triads, or transverse tubules were isolated by density gradient centrifugation as described previously in detail [18]. During all separation steps, a protease inhibitor cocktail was used to prevent excess proteolysis of high-molecular-mass muscle proteins [20]. The dystrophin-glycoprotein complex was isolated from microsomes by the method of Ervasti and coworkers [21].

\section{Gel electrophoresis}

Protein samples were separated on 3 to $12 \%$ gradient sodium dodecyl sulfate polyacrylamide gels and were stained with Coomassie Brilliant Blue or transferred to nitrocellulose [18]. Importantly, gel electrophoresis was carried out in the absence of combs so that several centimeter-long horizontal strips of individual muscle protein bands could be separated. The successful electrophoretic transfer of muscle proteins was evaluated by staining of nitrocellulose membranes with the reversible stain MemCode. Individual MemCode-stained bands were cut out for subsequent treatment with trypsin.

\footnotetext{
${ }^{1}$ Abbreviations used: LC-MS, liquid chromatography-mass spectrometry; PVP-40 polyvinylpyrrolidone; HPLC, high-performance liquid chromatography; MS/MS, tandem mass spectrometry.
} 
On-membrane digestion

Protein bands were excised from membranes, placed in a small plastic tube, destained, and washed five times with distilled water. Nitrocellulose strips were then blocked with $0.5 \%$ polyvinylpyrrolidone (PVP-40) at $37^{\circ} \mathrm{C}$ for $37 \mathrm{~min}$ with gentle shaking [16]. Membranes were subsequently washed five times with distilled water. For digestion, a fresh stock solution of $20 \mu \mathrm{g}$ trypsin in $1.5 \mathrm{ml}$ of buffer ( $100 \mathrm{mM}$ ammonium bicarbonate/10\% acetonitrile, $1: 1, \mathrm{v} / \mathrm{v}$ ) was prepared. Membrane strips were digested overnight at $37^{\circ} \mathrm{C}$ in $100 \mu \mathrm{l}$ of trypsin solution [22]. Subsequently, $100 \mu \mathrm{l}$ of extraction buffer ( $5 \%$ formic acid/acetonitrile, $1: 2, \mathrm{v} / \mathrm{v}$ ) was added to the trypsin-treated membranes and gently agitated for $15 \mathrm{~min}$ at $37^{\circ} \mathrm{C}$. All supernatant fractions were placed into fresh plastic tubes, and peptides were dried down by vacuum centrifugation [9]. Peptides were reconstituted in LC running buffer $(0.1 \%$ formic acid), centrifuged for $20 \mathrm{~min}$ in $22-\mu \mathrm{m}$ cellulose spin filter tubes to remove any membrane particles, and then aliquoted into LC-MS vials.

\section{Mass spectrometric analysis}

Recovered peptides were analyzed on an Agilent 6340 LC-MS instrument with a three-dimensional ion trap configuration (Agilent Technologies, Santa Clara, CA, USA) on a gradient of 5 to $100 \%$ acetonitrile $/ 0.1 \%$ formic acid for $10 \mathrm{~min}$. Separation of peptides was performed with a nanoflow Agilent 1200 series system equipped with a Zorbax 300SB C18 precolumn $(5 \mu \mathrm{m}, 4 \mathrm{~mm}$, $40 \mathrm{nl}$ ) and a Zorbax 300SB C18 analytical reversed phase column
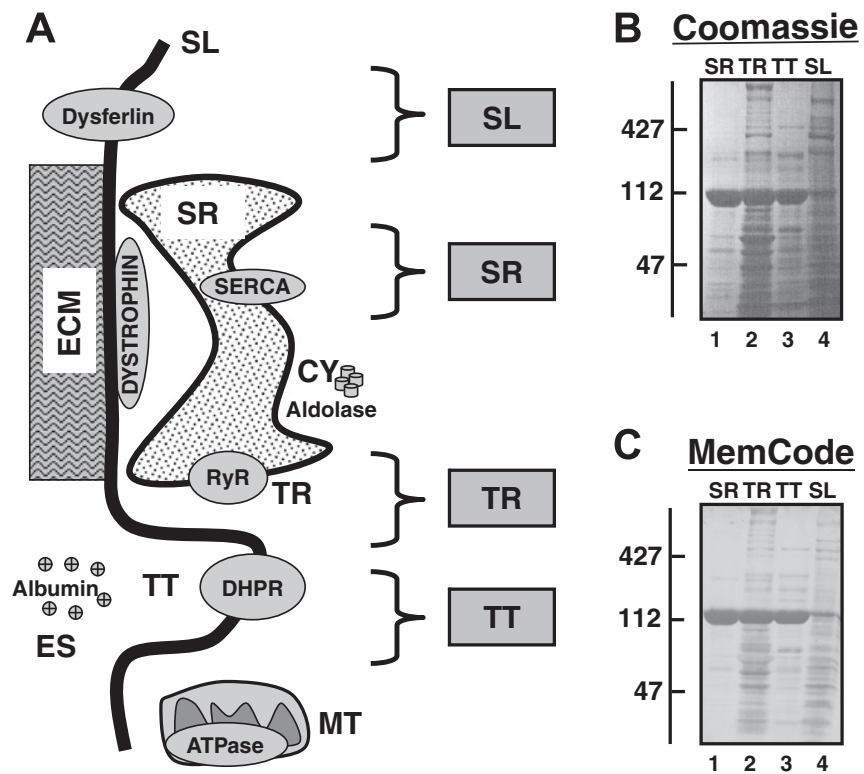

Fig. 2. Gel electrophoretic analysis of major subcellular fractions from skeletal muscle. (A) Diagrammatic presentation of major membrane systems in skeletal muscle fibers and the subcellular localization of established marker proteins. Membrane systems can be divided into the sarcolemma (SL), transverse tubules (TT), triad junctions (TR), sarcoplasmic reticulum (SR), and mitochondria (MT) whereby established markers of these fractions are represented by dysferlin, the dihydropyridine receptor (DHPR), the ryanodine receptor (RyR), $\mathrm{Ca}^{2+}$-ATPase isoform SERCA, and F1-ATPase, respectively. In addition, soluble elements of the extracellular space (ES), such as albumin, or abundant glycolytic enzymes of the cytosol (CY), such as aldolase, may become entrapped in vesicular membrane preparations derived from muscle homogenates. (B) Coomassie-stained gel of the sarcoplasmic reticulum, triads, transverse tubules, and sarcolemma. (C) Nitrocellulose replica of the sarcoplasmic reticulum, triads, transverse tubules, and sarcolemma stained with the reversible dye MemCode. Molecular mass standards (in $\mathrm{kDa}$ ) are shown on the left of panels B and C.
(5 $\mu \mathrm{m}, 43 \mathrm{~mm} \times 75 \mu \mathrm{m})$ using high-performance liquid chromatography (HPLC)-chip technology. Mobile phases used were A ( $0.1 \%$ formic acid) and B (90\% acetonitrile and $0.1 \%$ formic acid). Samples $(5 \mu \mathrm{l})$ were loaded into the enrichment at a capillary flow rate set to $4 \mu \mathrm{l} / \mathrm{min}$ with a mix of $A$ and $B$ at a ratio 19:1. Tryptic peptides were eluted with a linear gradient of 5 to $70 \%$ solvent B over $6 \mathrm{~min}, 70$ to $100 \%$ for $1 \mathrm{~min}$, and $100 \%$ for $1 \mathrm{~min}$ with a constant nano pump flow of $0.60 \mathrm{ml} / \mathrm{min}$. A 1-min posttime of solvent A was used to remove sample carryover. The capillary voltage was set to $2000 \mathrm{~V}$. The flow and temperature of the drying gas were $4 \mathrm{~L} /$ min and $300{ }^{\circ} \mathrm{C}$, respectively. Identified peptides were used to determine the protein species present in distinct protein bands. Database searches were carried out with a Mascot tandem mass spectrometry (MS/MS) ion search (Matrix Science, London, UK, NCBI database, release 20100212).

\section{Results}

To separate the high-molecular-mass band of dystrophin from other large muscle proteins and be able to visualize and identify a distinct Dp427-containing band, we have employed a combination of subcellular fractionation, gradient gel electrophoresis, onmembrane digestion, and mass spectrometry. The flowchart in Fig. 1 outlines the subcellular fractionation approach to separate the sarcolemma-enriched fraction from nuclei, cellular debris, the contractile apparatus, mitochondria, cytosolic proteins, triad junctions, transverse tubules, and the sarcoplasmic reticulum. In con-

\section{MemCode-stained sarcolemma}

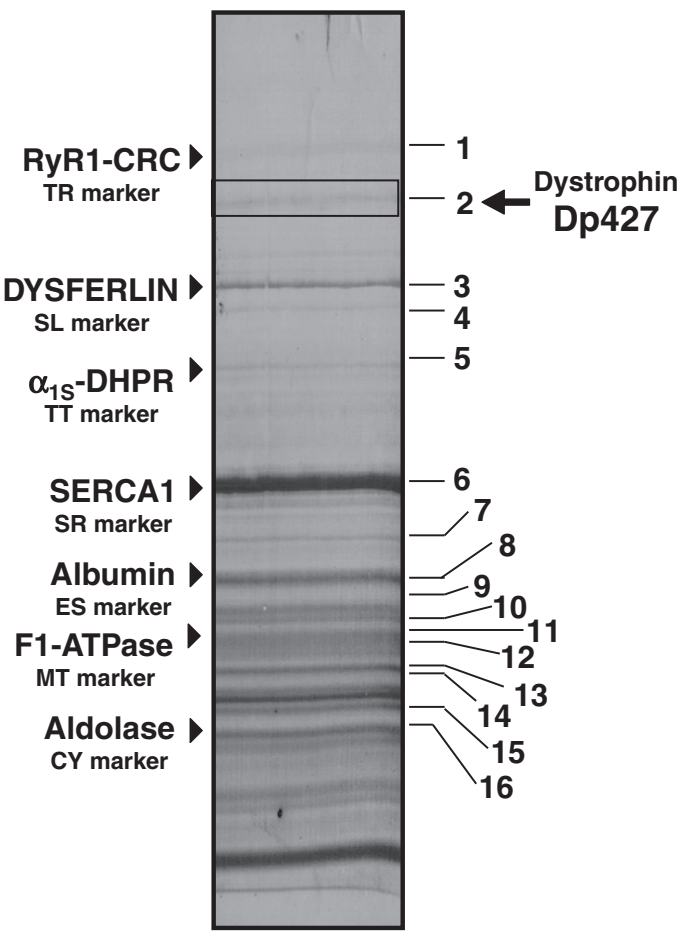

Fig. 3. Identification of full-length dystrophin isoform Dp427 by on-membrane digestion of the sarcolemma-enriched fraction from rabbit skeletal muscle. Shown is a representative MemCode-stained nitrocellulose replica of the electrophoretically separated sarcolemma-enriched fraction using a gel system without a comb for the generation of several centimeter-long horizontal bands for on-membrane digestion. Protein bands that were identified unequivocally by mass spectrometry are numbered 1 to 16 (Table 1 ), including elements of the dystrophin-glycoprotein complex such as dystrophin isoform Dp427 (band 2) and $\alpha$-syntrophin (band 10). On the left side of the panel are marked established marker proteins of the various subcellular fractions of muscle, as described in Fig. 2. 
Table 1

\begin{tabular}{|c|c|c|c|c|c|c|c|c|}
\hline $\begin{array}{l}\text { Band } \\
\text { number }\end{array}$ & Name of identified protein & Peptide sequence & $\begin{array}{l}\text { Peptides } \\
\text { matched }\end{array}$ & $\begin{array}{l}\text { Coverage } \\
(\%)\end{array}$ & $\begin{array}{l}\text { Molecular mass } \\
(\mathrm{kDa})\end{array}$ & $\begin{array}{l}\text { Isoelectric point } \\
(\mathrm{p} I)\end{array}$ & $\begin{array}{l}\text { Mascot } \\
\text { score }\end{array}$ & $\begin{array}{l}\text { Accession } \\
\text { number }\end{array}$ \\
\hline 1 & Ryanodine receptor, RyR1 isoform, skeletal muscle & $\begin{array}{l}\text { DLYALYPLLIR } \\
\text { GEGGSGLLAAIEEAIR } \\
\text { LVSTLLVMGIFGDEDVKQILK }\end{array}$ & 3 & 1 & 570.381 & 5.61 & 176 & gi|156119408| \\
\hline 2 & Full-length dystrophin, Dp427 isoform, skeletal muscle & $\begin{array}{l}\text { FAAISHR } \\
\text { LGLLLHDSIQIPR } \\
\text { LLDLLEGLTGQKLPK } \\
\text { SPAQILISLESEERGELER }\end{array}$ & 4 & 1 & 427.067 & 5.63 & 224 & gi|5032283| \\
\hline 3 & Dysferlin & $\begin{array}{l}\text { FVSLFEQK } \\
\text { TAIEILAWGLR } \\
\text { GSQPAGELLASFELIQR } \\
\text { TGPAAVFALEGALGGVVDDR }\end{array}$ & 4 & 2 & 241.329 & 5.42 & 245 & gi|156523092| \\
\hline 4 & Myosin heavy chain MHC1, skeletal muscle & $\begin{array}{l}\text { GSSFQTVSALFR } \\
\text { VIQYFATIAVTGEK } \\
\text { GKPEAHFSLVHYAGTVDYNIVGWLDKNK }\end{array}$ & 3 & 2 & 224.063 & 5.62 & 77 & gi|109113269| \\
\hline 5 & Dihydropyridine receptor, $\alpha_{1 \mathrm{~S}}$ subunit, skeletal muscle & $\begin{array}{l}\text { KPLPEVLPRPPR } \\
\text { ISSAFFR } \\
\text { HLDVVTLLR } \\
\text { TGGLFGQVDTFLER }\end{array}$ & 4 & 2 & 214.002 & 6.16 & 162 & gi|156119412| \\
\hline 6 & $\begin{array}{l}\text { Calcium-transporting ATPase, fast SERCA1 isoform, } \\
\text { skeletal muscle }\end{array}$ & $\begin{array}{l}\text { RIGIFGENEEVADR } \\
\text { EPLISGWLFFR } \\
\text { ALDLTQWLMVLK } \\
\text { ISLPVIGLDEILK }\end{array}$ & 4 & 4 & 111.756 & 5.14 & 219 & gi|147903853| \\
\hline 7 & Phosphofructokinase, skeletal muscle & $\begin{array}{l}\text { ITEIVDAITTTAQSHQR } \\
\text { LNIIIVAEGAIDR }\end{array}$ & 2 & 3 & 86.005 & 8.49 & 154 & gi|125128| \\
\hline 8 & Albumin & $\begin{array}{l}\text { SEIAHR } \\
\text { FNDVGEEHFIGLVLITFSQYLQK } \\
\text { RHPDYSVVLLLR }\end{array}$ & 3 & 6 & 70.861 & 5.85 & 107 & gi|126723746| \\
\hline 9 & Calsequestrin, isoform CSQ-1, skeletal muscle & $\begin{array}{l}\text { QFEMEELILELAAQVLEDK } \\
\text { ELQAFENLEDENK }\end{array}$ & 2 & 7 & 45.762 & 3.99 & 152 & gi|149755961| \\
\hline 10 & Syntrophin, $\alpha_{1}$-subunit, skeletal muscle & $\begin{array}{l}\text { TGLLELR } \\
\text { GSVPYDAELSFALR }\end{array}$ & 2 & 4 & 54.187 & 6.06 & 104 & gi|1438772| \\
\hline 11 & $\begin{array}{l}\text { ATP synthase, mitochondrial F1 complex, } \beta \text {-subunit } \\
\text { isoform } 2\end{array}$ & $\begin{array}{l}\text { GLTPSASLPPAQLLLR } \\
\text { TVLIMELINNVAK } \\
\text { FTQAGSEVSALLGR }\end{array}$ & 3 & 8 & 56.410 & 5.20 & 195 & gi|114644226| \\
\hline 12 & Tripartite motif-containing TRIM72 protein & $\begin{array}{l}\text { VFLAALEGSLDR } \\
\text { ALMPALEELTFDPSSAHPSLVVSPTGR }\end{array}$ & 2 & 8 & 53.601 & 5.92 & 137 & gi|126723064| \\
\hline 13 & Flotillin & $\begin{array}{l}\text { TEAEIAHIALETLEGHQR } \\
\text { VTGEVLDILSR }\end{array}$ & 2 & 6 & 47.769 & 6.71 & 79 & gi|6679809| \\
\hline 14 & Enolase & $\begin{array}{l}\text { AVEHINK } \\
\text { HITGQK }\end{array}$ & 2 & 2 & 47.381 & 7.63 & 58 & gi|126723437| \\
\hline 15 & Muscle creatine kinase & $\begin{array}{l}\text { LNYKSEEEYPDLSK } \\
\text { VLTPDLYK } \\
\text { LSVEALNSLTGEFK } \\
\text { FEEILTR }\end{array}$ & 4 & 11 & 43.433 & 6.63 & 186 & gi|6729828| \\
\hline 16 & Aldolase & $\begin{array}{l}\text { ELSDIAHR } \\
\text { IGEHTPSALAIMENANVLAR } \\
\text { YSHEEIAMATVTALR }\end{array}$ & 3 & 11 & 39.586 & 8.20 & 164 & gi|6730618| \\
\hline
\end{tabular}


trast to the highly evolved sarcoplasmic reticulum and associated triad structures, the plasmalemma from skeletal muscle represents a much less abundant membrane system [18]. Hence, it cannot be prevented that various abundant membrane species cross-contaminate sarcolemmal preparations during differential and density gradient centrifugation steps. The major membranes of skeletal muscle tissues are shown diagrammatically in Fig. 2A. For comparative purposes, the subcellular localization of marker proteins that were identified by mass spectrometry in this study is illustrated in this figure panel. The Coomassie-stained gel in Fig. 2B illustrates the considerably different protein band pattern of the sarcoplasmic reticulum, triad junctions, transverse tubules, and sarcolemma. Following electroblotting, the successful transfer of proteins was visualized by staining of nitrocellulose replicas with the reversible stain MemCode (Fig. 2C).

As shown in the representative nitrocellulose sheet in Fig. 3, for the mass spectrometric analysis of the sarcolemma-enriched fraction, gel electrophoresis of muscle proteins was performed without combs so that several centimeter-long horizontal strips of individual protein bands could be separated. MemCode-stained nitrocellulose sheets were cut into 41 bands and then digested with trypsin. The mass spectrometric analysis identified 16 individual muscle proteins with a high Mascot score [23,24], as listed in Table 1 . Protein bands 1 to 16 contained several established marker proteins of subcellular fractions from skeletal muscle. Bands 1, 3, 4, $5,6,11$, and 16 represent the ryanodine receptor $\mathrm{Ca}^{2+}$-release channel isoform RyR1 of the triad junction, dysferlin of the sarcolemma, myosin heavy chain MHC1 of the contractile apparatus, the voltage-sensing $\alpha_{15}$-subunit of the dihydropyridine receptor L-type $\mathrm{Ca}^{2+}$ channel of the transverse tubules, the fast SERCA1 isoform of the sarcoplasmic reticulum $\mathrm{Ca}^{2+}$-ATPase, the mitochondrial F1-ATPase, and the abundant glycolytic enzyme aldolase of the cytosol, respectively. Thus, besides an enrichment of the sarcolemmal marker dysferlin, the plasma membrane preparation analyzed in this article contained contaminating or associated structures from the actomyosin apparatus and most major membrane systems present in contractile fibers. Other proteins present in this subcellular fraction were phosphofructokinase, albumin, calsequestrin, TRIM72 protein, and flotillin (Table 1 ). Several proteins could be identified by only one matched peptide and, therefore, are not listed in Table 1. These included succinate dehydrogenase (LGANSLLDLVVFGR, 2\% coverage, $73.670 \mathrm{kDa}$, pI 7.06, Mascot score $=75$, gi|347134|), the $\alpha$-subunit of sarcoglycan (DSFDTAGQSLVLLIR, 3\% coverage, 42.984 $\mathrm{kDa}$, pI 5.76, Mascot score $=57$, gi|126722611|), muscle creatine kinase (LSVEALNSLTGEFK, 3\% coverage, $43.247 \mathrm{kDa}$, pI 6.63, Mascot score $=56$, gi $|180576|$ ), and the $\alpha$-chain of G protein (NVQFVFDAV TDVIIK, $4 \%$ coverage, $41.100 \mathrm{kDa}$, pI 5.36, Mascot score $=68$, gi|309255|).

Most important, as shown in Fig. 3, the mass spectrometric analysis of the sarcolemma-enriched fraction by on-membrane digestion identified the low-abundance membrane cytoskeletal protein dystrophin (band 2) as well as the tightly dystrophin-associated protein $\alpha$-syntrophin (band 10). Previous mass spectrometry-based proteomic profiling studies of total soluble skeletal muscle extracts have failed to detect dystrophin or its associated membrane proteins [6-10]. In analogy, Fig. 4 shows the mass spectrometric analysis of the purified dystrophin-glycoprotein complex, and Table 2 lists the details of the mass spectrometric identification of dystrophin (band 1), $\alpha$-sarcoglycan (band 2), and $\gamma$-sarcoglycan (band 3). The dystrophin-associated protein dystrobrevin could be identified by only one matched peptide (LEAVLSTIFYQLNK, 2\% coverage, $78.425 \mathrm{kDa}, \mathrm{pI}$ 6.34, Mascot score $=70$, gi $|1246783|$ ) and, therefore, is not listed in Table 2. Representative results from LC-MS analysis and mass spectra of dystrophin from sarcolemmal preparations and the isolated dystrophin-glycoprotein complex are shown in Fig. 5.

\section{Discussion}

Besides defining the physical integrity within contractile tissues by separating the fiber interior from the extracellular milieu, the highly complex surface membrane system of skeletal muscle fibers plays a central physiological role in the neuromuscular transmission process, the propagation of action potentials, the maintenance of ion homeostasis, the regulation of excitation-contraction coupling, the control of metabolic fluxes, and the provision of cellular signaling cascades for the swift physiological adaptation to changed functional demands. The biomedical fact that primary genetic abnormalities in proteins located on the surface membrane system are responsible for various neuromuscular pathologies emphasizes the importance of a detailed biochemical understanding of the composition and structure of the plasma membrane from skeletal muscle tissues. Individual sarcolemmal proteins have been studied for many years using conventional biochemical approaches, but their global protein composition is poorly understood. One possible way forward to catalogue the entire membrane protein complement of the fiber periphery is mass spectrometry-based proteomics.

Proteomics has had a major impact on the modern biosciences [25] and has decisively enhanced the field of basic and applied myology [26]. Proteomic profiling of muscle development, fiber differentiation, and muscle transformation has identified a large cohort of new potential markers of muscle biochemistry and their role in physiological adaptations to changed functional demands [27]. Mass spectrometry was also instrumental in the global
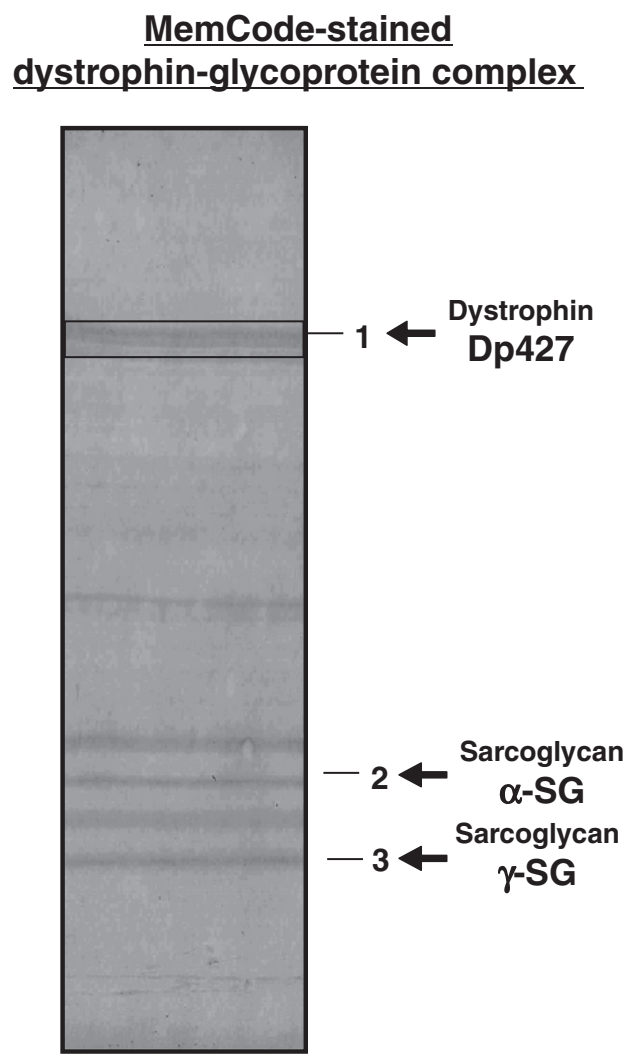

Fig. 4. Identification of dystrophin by on-membrane digestion of the purified dystrophin-glycoprotein complex from rabbit skeletal muscle. Shown is a representative MemCode-stained nitrocellulose replica of the electrophoretically separated dystrophin-glycoprotein complex using a gel system without a comb for the generation of several centimeter-long horizontal bands for on-membrane digestion. Protein bands that were identified unequivocally by mass spectrometry are numbered 1 to 3 (Table 2): dystrophin isoform Dp427 (band 1), $\alpha$-sarcoglycan (band 2), and $\gamma$-sarcoglycan (band 3 ). 
Table 2

Mass spectrometric identification of electrophoretically separated protein bands from purified dystrophin-glycoprotein complex.

\begin{tabular}{|c|c|c|c|c|c|c|c|c|}
\hline $\begin{array}{l}\text { Band } \\
\text { number }\end{array}$ & Name of identified protein & Peptide sequence & $\begin{array}{l}\text { Peptides } \\
\text { matched }\end{array}$ & $\begin{array}{l}\text { Coverage } \\
(\%)\end{array}$ & $\begin{array}{l}\text { Molecular } \\
\text { mass (kDa) }\end{array}$ & $\begin{array}{l}\text { Isoelectric } \\
\text { point }(\mathrm{p} I)\end{array}$ & $\begin{array}{l}\text { Mascot } \\
\text { score }\end{array}$ & $\begin{array}{l}\text { Accession } \\
\text { number }\end{array}$ \\
\hline 1 & $\begin{array}{l}\text { Full-length dystrophin, Dp427 } \\
\text { isoform, skeletal muscle }\end{array}$ & $\begin{array}{l}\text { LLDLLEGLTGQQLPK } \\
\text { SPAQILISLESEERGELER } \\
\text { ILADLEEENRNLQAEYDR } \\
\text { ILAQTLTDGGVMDELINEELETFNSR }\end{array}$ & 4 & 2 & 430.340 & 5.67 & 249 & gi|119619468| \\
\hline 2 & Sarcoglycan, $\alpha$-subunit & $\begin{array}{l}\text { SPHHPGFLYGAATPEDR } \\
\text { QVIEVTAYNR } \\
\text { DSFDTAGQSLVLLIR }\end{array}$ & 3 & 10 & 42.993 & 5.76 & 158 & gi|126722611| \\
\hline 3 & Sarcoglycan, $\gamma$-subunit & $\begin{array}{l}\text { LEGESEFLFPLYAK } \\
\text { VTGPEGALFEHSVETPLVTADPFQDLR }\end{array}$ & 2 & 14 & 32.359 & 5.12 & 90 & gi|126723675| \\
\hline
\end{tabular}
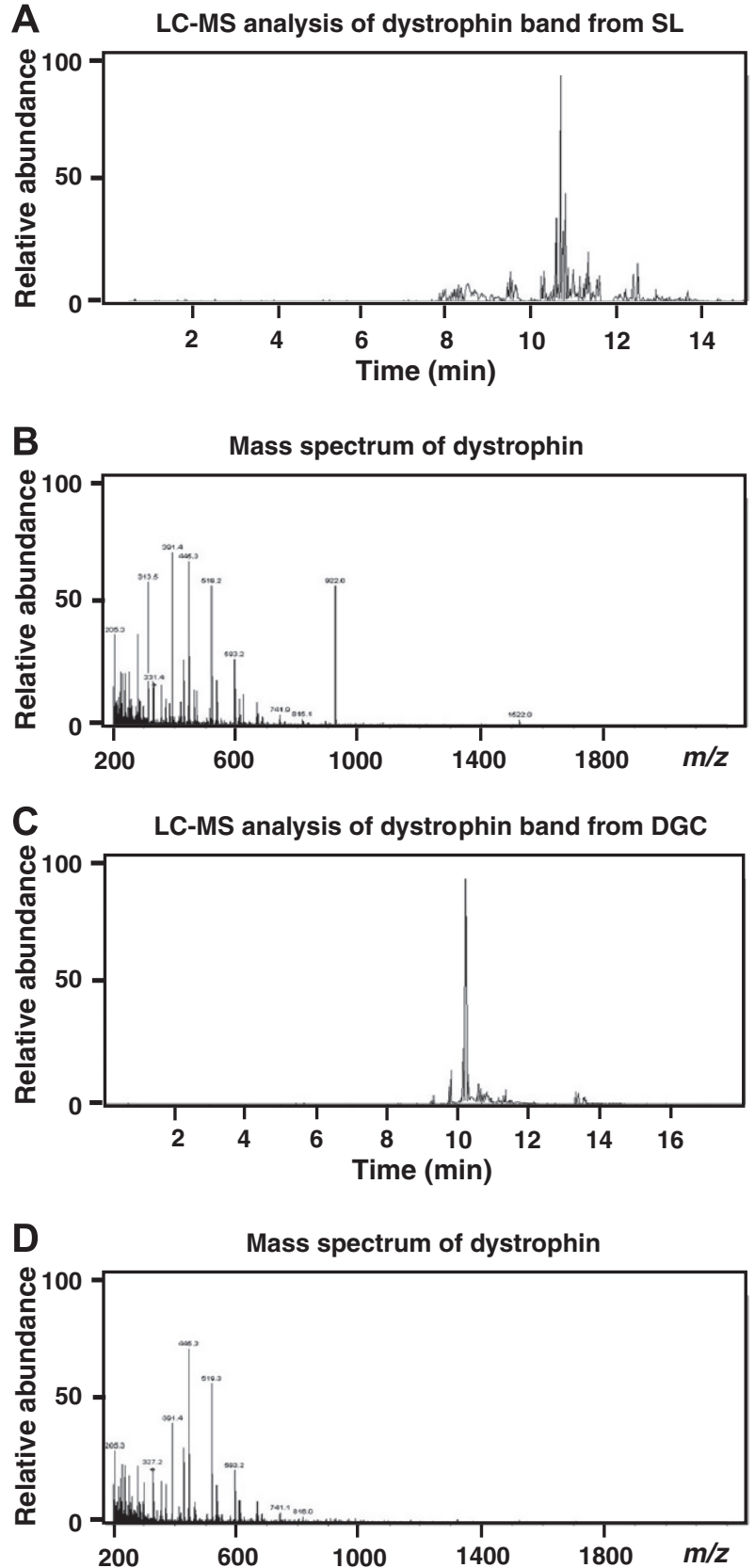

Fig. 5. Identification of full-length dystrophin isoform Dp427. Shown is the LC-MS analysis of the dystrophin band isolated from the sarcolemma-enriched membrane fraction (SL) (A) and the purified dystrophin-glycoprotein complex (DGC) (C) from rabbit skeletal muscle. Mass spectra of dystrophin are presented in panels $\mathrm{B}$ and D. analysis of common neuromuscular disease mechanisms. The proteomic analysis of muscular disorders has identified novel signature molecules involved in the molecular pathogenesis of muscular dystrophy and age-related muscle weakness $[10,28]$. However, the majority of these studies have focused on the analysis of total extracts of the accessible skeletal muscle proteome. Because the routine gel electrophoretic separation of crude protein extracts greatly underestimates the presence of integral proteins, low-abundance elements, high-molecular-mass proteins, and components with extremely acidic or basic $\mathrm{pI}$ values, previous analyses have been restricted to relatively soluble protein species. This is probably the main reason why proteomic studies of skeletal muscle tissues identify mostly abundant and soluble proteins such as heat shock proteins, glycolytic enzymes, and contractile proteins [6-10,26-28]. However, the results shown here suggest that a modified subproteomic approach can be employed to also study membrane-associated and high-molecular-mass muscle proteins.

The successful identification of dystrophin isoform Dp427, as described in this article, demonstrates that one-dimensional gel electrophoresis, in combination with on-membrane digestion, can overcome some of the technical problems of conventional two-dimensional gel electrophoretic techniques. Thus, to include the analysis of membrane-associated proteins in mass spectrometric studies, it is recommended to combine two-dimensional gel electrophoretic analyses of crude muscle extracts with on-membrane digestion approaches of distinct subcellular fractions. Such an inclusive biochemical approach might be especially useful for the comparative proteomic screening of neuromuscular disorders where integral membrane proteins are often affected by complex downstream abnormalities in muscle metabolism, signal transduction, and ion homeostasis.

\section{Acknowledgments}

Research was supported by a project grant from Muscular Dystrophy Ireland and a Hume Scholarship from the National University of Ireland, Maynooth.

\section{References}

[1] K.P. Campbell, Three muscular dystrophies: loss of cytoskeleton-extracellular matrix linkage, Cell 80 (1995) 675-679.

[2] K. Ohlendieck, Towards an understanding of the dystrophin-glycoprotein complex: linkage between the extracellular matrix and the subsarcolemmal membrane cytoskeleton, Eur. J. Cell Biol. 69 (1996) 1-10.

[3] J.M. Ervasti, K.J. Sonnemann, Biology of the striated muscle dystrophinglycoprotein complex, Int. Rev. Cytol. 265 (2008) 191-225.

[4] M. Koenig, L.M. Kunkel, Detailed analysis of the repeat domain of dystrophin reveals four potential hinge segments that may confer flexibility, J. Biol. Chem. 265 (1990) 4560-4566.

[5] K. Ohlendieck, K. Matsumura, V.V. Ionasescu, J.A. Towbin, P. Bosch, S.L. Weinstein, S.W. Sernett, K.P. Campbell, Duchenne muscular dystrophy: deficiency of dystrophin-associated proteins in the sarcolemma, Neurology 43 (1993) 795-800. 
[6] Y. Ge, M.P. Molloy, J.S. Chamberlain, P.C. Andrews, Proteomic analysis of mdx skeletal muscle: great reduction of adenylate kinase 1 expression and enzymatic activity, Proteomics 3 (2003) 1895-1903.

[7] P. Doran, P. Dowling, J. Lohan, K. McDonnell, S. Poetsch, K. Ohlendieck, Subproteomics analysis of $\mathrm{Ca}^{2+}$-binding proteins demonstrates decreased calsequestrin expression in dystrophic mouse skeletal muscle, Eur. J. Biochem. 271 (2004) 3943-3952.

[8] P. Doran, P. Dowling, P. Donoghue, M. Buffini, K. Ohlendieck, Reduced expression of regucalcin in young and aged $\mathrm{mdx}$ diaphragm indicates abnormal cytosolic calcium handling in dystrophin-deficient muscle, Biochim. Biophys. Acta 1764 (2006) 773-785.

[9] P. Doran, G. Martin, P. Dowling, H. Jockusch, K. Ohlendieck, Proteome analysis of the dystrophin-deficient MDX diaphragm reveals a drastic increase in the heat shock protein cvHSP, Proteomics 6 (2006) 4610-4621.

[10] C. Lewis, S. Carberry, K. Ohlendieck, Proteomic profiling of X-linked muscular dystrophy, J. Muscle Res. Cell Motil. 30 (2009) 267-279.

[11] A. Goerg, W. Weiss, M.J. Dunn, Current two-dimensional electrophoresis technology for proteomics, Proteomics 4 (2004) 3665-3685.

[12] B. Wittmann-Liebold, H.R. Graack, T. Pohl, Two-dimensional gel electrophoresis as tool for proteomics studies in combination with protein identification by mass spectrometry, Proteomics 6 (2006) 4688-4703.

[13] T. Rabilloud, A.R. Vaezzadeh, N. Potier, C. Lelong, E. Leize-Wagner, M. Chevallet, Power and limitations of electrophoretic separations in proteomics strategies, Mass Spectrom. Rev. 28 (2009) 816-843.

[14] J.L. Luque-Garcia, G. Zhou, T.T. Sun, T.A. Neubert, Use of nitrocellulose membranes for protein characterization by matrix-assisted laser desorption/ ionization mass spectrometry, Anal. Chem. 78 (2006) 5102-5108.

[15] J.L. Luque-Garcia, G. Zhou, D.S. Spellman, S. Tung-Tien, T.A. Neubert, Analysis of electroblotted proteins by mass spectrometry: protein identification after Western blotting, Mol. Cell. Proteomics 7 (2008) 308-314.

[16] R.H. Aebersold, J. Leavitt, R.A. Saavedra, L.E. Hood, S.B. Kent, Internal amino acid sequence analysis of proteins separated by one- or two-dimensional gel electrophoresis after in situ protease digestion on nitrocellulose, Proc. Natl. Acad. Sci. USA 84 (1987) 6970-6974.

[17] J.L. Luque-Garcia, T.A. Neubert, On-membrane tryptic digestion of proteins for mass spectrometry analysis, Methods Mol. Biol. 536 (2009) 331-341.

[18] K. Ohlendieck, J.M. Ervasti, J.B. Snook, K.P. Campbell, Dystrophin glycoprotein complex is highly enriched in skeletal muscle sarcolemma, J. Cell Biol. 112 (1991) 135-148.

[19] K. Ohlendieck, K.P. Campbell, Dystrophin constitutes 5\% of membrane cytoskeleton in skeletal muscle, FEBS Lett. 283 (1991) 230-234.

[20] K. Ohlendieck, Membrane cytoskeletal characterisation of utrophin in highly purified sarcolemma vesicles, Biochim. Biophys. Acta 1283 (1996) 215-222.

[21] J.M. Ervasti, K. Ohlendieck, S.D. Kahl, M.G. Gaver, K.P. Campbell, Deficiency of a glycoprotein component of the dystrophin complex in dystrophic muscle, Nature 345 (1990) 315-319.

[22] A. Shevchenko, H. Tomas, J. Havlis, J.V. Olsen, M. Mann, In-gel digestion for mass spectrometric characterization of proteins and proteomes, Nat. Protoc. 1 (2006) 2856-2860.

[23] D.N. Perkins, D.J. Pappin, D.M. Creasy, J.S. Cottrell, Probability-based protein identification by searching sequence databases using mass spectrometry data, Electrophoresis 20 (1999) 3551-3567.

[24] T. Koenig, B.H. Menze, M. Kirchner, F. Monigatti, K.C. Parker, J.J. Steen, F.A. Hamprecht, H. Steen, Robust prediction of the Mascot score for an improved quality assessment in mass spectrometric proteomics, J. Proteome Res. 7 (2008) 3708-3717.

[25] C.L. de Hoog, M. Mann, Proteomics, Annu. Rev. Genomics Hum. Genet. 5 (2004) 267-293.

[26] R.J. Isfort, Proteomic analysis of striated muscle, J. Chromatogr. B 771 (2002) 155-165.

[27] K. Ohlendieck, Proteomics of skeletal muscle differentiation, neuromuscular disorders, and aging, Expert Rev. Proteomics 7 (2010) 283-296.

[28] P. Doran, P. Donoghue, K. O'Connell, J. Gannon, K. Ohlendieck, Proteomics of skeletal muscle aging, Proteomics 9 (2009) 989-1003. 